\title{
HUBUNGAN CARING PERAWAT DENGAN TINGKAT KECEMASAN KELUARGA PASIEN KOMA DI RUANG INTENSIF
}

\author{
Wahyu Rima Agustin 1), Anita Isti \\ 1,2,3,4 Prodi Profesi Ners Universitas Kusuma \\ Husada Surakarta
}

\section{Corresponding author:} Wahyu Rima Agustin

Prodi Profesi Ners Universitas Kusuma Husada Surakarta

Email: wra.wahyurimaagustin@gmail.com

\section{Article Info:}

Dikirim: 11 Maret 2020

Ditinjau: 2 April 2020

Diterima: 9 April 2020

\section{DOI:}

https://doi.org/10.33475/jikmh.v9i1.212

\section{Abstract}

Caring is an intervention, which is done to provide support to an individual as a whole. The caring extended to coma patients at an intensive care unit can induce worries, which lead to the sense of discomfort so that the families of the patients feel anxious. With the existence of nurses' good caring, the anxiety of the families can be lessen. The objective of this research is to analyze the correlation between the nurses' caring and the anxiety level of the families of coma patients at the intensive of care unit of Dr.Soehadi Prijonegoro Local General Hospital of Sragen.

This research used the quantitative correlational research method with the cross sectional design. Its population was all of the families of the coma patients at the intensive of care unit of Dr.Soehadi Prijonegoro Local General Hospital of Sragen. Quota sampling technique was used to determine its samples. The samples consisted of 30 respondents who fulfilled the inclusive criteria. The data of the research were analyzed by using the Kendal Tau's Test. The measuring tools of the research were Caring Behaviors Assessment Tool (CBAT) and Hamilton Anxiety Rating Scale (HARS).

The result of the research shows that most of the respondents (86.7\%) an adequately good perception on the nurses' caring and most of the respondents (83.3\%) had a moderate anxiety level. Thus, there was a significant strong correlation between the nurses' caring and the anxiety level of the families of coma patients at the intensive of care unit of Dr.Soehadi Prijonegoro Local General Hospital of Sragen as indicated by the $p$-value $=0.000$ ( $p$-value $<0.05)$, and the $r$-value $=-0.678$.

Keywords: Caring; anxiety; families

\begin{abstract}
Abstrak
Caring merupakan suatu tindakan yang dilakukan dalam memberikan dukungan kepada individu secara utuh. Perawatan di ruang intensif dengan kondisi pasien dalam keadaan koma dapat menyebabkan kekhawatiran yang akan menimbulkan rasa ketidaknyamanan sehingga keluarga mengalami kecemasan, dengan adanya caring perawat yang baik maka kecemasan yang dirasakan keluarga dapat berkurang. Penelitian ini bertujuan untuk menganalisa hubungan caring perawat dengan tingkat kecemasan keluarga pasien koma di ruang intensif.

Jenis penelitian ini adalah penelitian kuantitatif dengan rancangan korelasional menggunakan cross sectional. Populasi dalam penelitian ini adalah semua keluarga pasien koma di ruang intensif RSUD Dr.Soehadi Prijonegoro Sragen. Pemilihan sampel dilakukan dengan metode quota sampling yaitu sebanyak 30 responden yang memenuhi kriteria inklusi. Analisa data dalam penelitian ini menggunakan analisa uji Kendal Tau. Alat ukur dalam penelitian ini menggunakan Caring Behaviors Assessment Tool (CBAT) dan Hamilton Anxiety Rating Scale (HARS).

Hasil penelitian ini menunjukkan sebagian besar responden (86.7\%) mempunyai persepsi caring perawat dalam kategori cukup dan responden (83.3\%) mengalami tingkat kecemasan sedang. Hasil penelitian didapatkan ada hubungan yang signifikan antara caring perawat dengan tingkat kecemasan keluarga pasien koma di ruang intensif RSUD Dr.Soehadi Prijonegoro Sragen p value 0,000 (p value $<0,05)$, dengan arah hubungan kuat dengan nilai korelasi $r=-0,678$.
\end{abstract}

Kata Kunci: Caring; Kecemasan; Keluarga 


\section{PENDAHULUAN}

Pasien koma merupakan seseorang yang mengalami penurunan kesadaran yang sangat dalam dengan kondisi kritis atau keadaan sakit berat serta kondisinya tidak stabil, biasanya pasien koma ditempatkan di ruang intensive. Kondisi pasien dalam keadaan koma dengan terpasangnya beberapa alat yang cukup banyak dan ditambah perawatan di ruang intensif menjadikan peran keluarga terhadap pasien berkurang. Hal tersebut terjadi karena keluarga tidak banyak terlibat dalam proses perawatan pasien serta tidak dapat mendampingi pasien di ruang intensif setiap saat, sehingga keluarga akan mengalami kecemasan. Kecemasan merupakan keadaan perasaan afektif yang tidak menyenangkan yang disertai dengan sensasi fisik yang memperingatkan orang terhadap bahaya yang akan datang (Lestari, 2015).

Berdasarkan penelitian yang dilakukan Elias dkk (2013), menunjukkan hasil bahwa tingkat kecemasan keluarga di Ruang High Care Unit (HCU) Rumah Sakit Immanuel Bandung sebagian besar tergolong pada kategori cemas sedang sebanyak 40 responden $(74,1 \%)$, artinya bahwa kecemasan keluarga selama di Ruang High Care Unit (HCU) membutuhkan perhatian dan kepedulian perawat. Pada saat keluarga pasien mengalami kecemasan maka caring perawat terhadap keluarga pasien sangat dibutuhkan. Caring merupakan suatu tindakan yang dilakukan dalam memberikan dukungan kepada individu secara utuh (Dwidiyanti, 2007). Berdasarkan penelitian Setiyawan (2014), mayoritas perawat yang kurang caring sebesar 7,3\% dan cukup caring sebesar 43,6\%.

Berdasarkan wawancara yang dilakukan peneliti kepada keluarga pasien, menyatakan bahwa sebagian perawat jarang berinteraksi langsung dengan keluarga pasien, perawat hanya berkomunikasi apabila ada keperluan penting yang berkaitan dengan keadaan pasien, maupun pengurusan surat-surat yang harus disepakati oleh keluarga pasien. Kecemasan keluarga pasien koma ditunjukkan dengan pandangan kosong, melamun dan gelisah. Keluarga pasien merasa cemas karena melihat kondisi pasien mengalami penurunan kesadaran dan banyak alat-alat medis yang terpasang pada pasien, selain itu keluarga selalu memikirkan biaya perawatan yang harus dibayarkan, sedangkan kecemasan keluarga pasien yang tidak koma, mereka lebih tenang dibandingkan dengan keluarga pasien koma.

Hasil observasi melalui pengamatan peneliti di ruang ICU dan ICCU Rumah Sakit Dr. Soehadi Prijonegoro Sragen, perawat dalam melaksanakan tugas hanya sebagai suatu rutinitas serta memenuhi kewajiban pekerjaan saja. Hal tersebut tampak pada tindakan kolaborasi dengan dokter dalam pemberian obat, perawat memberikan injeksi tanpa melakukan komunikasi terapeutik dengan baik terhadap pasien maupun keluarga, selain itu dalam memantau tanda-tanda vital pasien, perawat hanya memantau melalui monitor tanpa melihat pasien secara langsung sehingga keluarga tampak cemas.

\section{METODE}

Penelitian ini dilakukan di ruang intensif RSUD Dr.Soehadi Prijonegoro Sragen pada bulan Juli 2017. Jenis penelitian ini adalah penelitian kuantitatif dengan rancangan penelitian korelasional. Penelitian ini dilakukan dengan menggunakan pendekatan Cross Sectional. Populasi dalam penelitian ini adalah semua keluarga pasien koma di ruang intensif RSUD Dr. Soehadi Prijonegoro Sragen.

Teknik sampling dalam penelitian ini menggunakan Quota Sampling. Quota Sampling adalah teknik untuk menentukan sampel dari populasi yang mempunyai ciriciri tertentu sampai jumlah (kuota) yang diinginkan (Sugiyono, 2012). Sampel pada penelitian ini berjumlah 30 responden. Alat pengumpulan data menggunakan kuesioner CBAT (Caring Behaviors Assessment Tool) yang dimodifikasi oleh peneliti dan tingkat kecemasan 
yang menggunakan kuesioner HARS (Hamilton Anxiety Rating Scale). Analisa univariat dalam penelitian ini adalah distribusi tentang umur, jenis kelamin, pendidikan, hubungan dengan pasien, tingkat kecemasan dan caring perawat. Analisa bivariat menggunakan uji Kendall Tau.

\section{HASIL DAN PEMBAHASAN}

1) Berdasarkan Usia

Hasil penelitian ini menunjukkan bahwa mayoritas keluarga pasien koma di ruang intensif masuk dalam kategori usia lansia awal yaitu sebanyak 16 responden (53.3\%). Usia berkaitan dengan banyaknya pengalaman masa lalu terhadap hal yang sama yang bisa menyebabkan kecemasan. Semakin bertambahnya usia seseorang akan semakin baik dalam mengendalikan emosinya dan menjalani kehidupan juga semakin matang serta baik dalam adaptasi terhadap kecemasan (Elias, 2013).

Peneliti berpendapat semakin bertambah umur seseorang, maka semakin matang dalam berfikir dan bekerja serta semakin meningkat pula kematangan jiwanya. Makin tua umur seseorang makin konsentrasi menggunakan koping dalam masalah yang dihadapi.

\section{2)Berdasarkan Jenis Kelamin}

Hasil penelitian ini menunjukkan bahwa mayoritas keluarga pasien koma di ruang intensif berjenis kelamin perempuan yaitu sebanyak 19 responden (63.3\%). Banyaknya responden perempuan dibandingkan dengan responden laki-laki lebih disebabkan responden perempuan merupakan anggota keluarga pasien yang berada di rumah atau tidak bekerja, sehingga waktu yang dimiliki lebih banyak sedangkan responden laki-laki lebih sedikit disebabkan responden sedang bekerja dan tidak dapat menjaga pasien (Ikawati VC \& Sulastri, 2011).

Menurut peneliti jenis kelamin merupakan sifat pribadi yang diartikan bahwa semua tingkah laku dan sifat sejak lahir ataupun yang memberikan karakteristik seseorang. Perempuan lebih memiliki sifat empati yang tinggi dibandingkan dengan laki-laki dan sumber kasih sayang, sedangkan laki-laki mereka memiliki sifat bertanggung jawab, bekerja untuk menafkahi keluarga jadi waktu yang dimiliki lebih sedikit.

\section{3)Berdasarkan Pendidikan}

Hasil penelitian ini menunjukkan bahwa mayoritas pendidikan keluarga pasien berpendidikan SMP yaitu sebanyak 19 responden (63.3\%). Hasil penelitian lain dari Astutik \& Yonathan (2008) menunjukkan bahwa mayoritas tingkat pendidikan dari 30 responden yaitu berpendidikan dasar (SMP) yaitu sebanyak 15 responden $(50,0 \%)$. Seseorang yang memiliki pendidikan tinggi mereka mempunyai sosialisasi dengan orang lain cukup tinggi, sehingga rasa empati pada orang lain juga tinggi, tetapi diterpa oleh banyak kesibukan sehingga mempengaruhi waktu yang kurang untuk keluarga, maka kompensasi yang diberikan adalah fasilitas yang lebih. Pantaslah ketika keluarga mereka berada diruang ICU mereka sulit ditemukan, hal ini dikarenakan mereka tahu dan merasa lebih aman alat-alat yang canggih melekat pada pasien membuat keluarga tetap pada rutinitas yang mereka kerjakan dan mereka percaya semua kebutuhan pasien akan terpenuhi dengan baik tanpa bantuan keluarga.

\section{4)Berdasarkan Hubungan Dengan Pasien}

Hasil penelitian ini menunjukkan bahwa sebagian besar responden mempunyai hubungan sebagai anak yaitu sebanyak 25 responden (83.3\%). Anak secara umum dikatakan sebagai keturunan kedua setelah ayah dan ibu. Anak merupakan buah dari pernikahan ke dua orang tua yang biasanya memiliki ikatan emosional yang kuat terhadap orang tua. Ikatan emosi yang kuat tersebut menjadi satu faktor yang mendorong seorang anak sehingga anak rela menunggu orang tua yang dirawat dirumah sakit. Selain ikatan emosi yang kuat seorang anak juga memiliki kewajiban berbakti dan bertanggung jawab merawat orang tua ketika orang tua sakit dan salah satu wujud dalam memenuhi kewajiban tersebut yaitu dengan 
menunggu dan merawat orang tua yang sedang dirawat di rumah sakit (Setiawati, B. 2009).

Tabel 1. Distribusi frekuensi keluarga pasien koma berdasarkan usia, jenis kelamin, pendidikan, dan hubungan dengan pasien di ruang intensif RSUD Dr.Soehadi Prijonegoro Sragen pada bulan Juli 2017 $(n=30)$

\begin{tabular}{|c|c|c|}
\hline Kategori & $\mathbf{F}$ & $\%$ \\
\hline \multicolumn{3}{|l|}{ 1. Usia } \\
\hline Remaja akhir & 1 & 3.3 \\
\hline Dewasa awal & 5 & 16.7 \\
\hline Dewasa akhir & 5 & 16.7 \\
\hline Lansia awal & 16 & 53.3 \\
\hline Lansia akhir & 3 & 10.0 \\
\hline \multicolumn{3}{|c|}{ 2. Jenis Kelamin } \\
\hline Laki-laki & 11 & 36.7 \\
\hline Perempuan & 19 & 63.3 \\
\hline \multicolumn{3}{|l|}{$\begin{array}{ll}\text { 3. } & \text { Pendidikan }\end{array}$} \\
\hline SD & 3 & 10.0 \\
\hline SMP & 19 & 63.3 \\
\hline SMA & 8 & 26.7 \\
\hline $\begin{array}{ll}\text { 4. } & \begin{array}{l}\text { Hubungan } \\
\text { Pasien }\end{array}\end{array}$ & & \\
\hline Suami/istri & 2 & 6.7 \\
\hline Anak & 25 & 83.3 \\
\hline Orang tua & 3 & 10.0 \\
\hline $\mathrm{N}=$ & 30 & $100 \%$ \\
\hline
\end{tabular}

a.Caring perawat di ruang intensif RSUD Dr.Soehadi Prijonegoro Sragen

Hasil penelitian ini menunjukkan bahwa sebagian besar responden mempunyai persepsi caring perawat dalam kategori caring cukup yaitu sebanyak 26 responden (86.7\%). Menurut Fadilah (2016) kriteria caring perawat cukup yaitu perawat mengenal siapa kliennya, menyediakan waktu bagi pasien dan keluarga walaupun sedang sibuk, mendengarkan keluhan pasien maupun keluarga, menghargai dan menghormati pendapat keluarga serta memberikan dukungan sosial.

Tabel 2. Distribusi frekuensi caring perawat

\begin{tabular}{lll}
\hline Kategori & $\mathrm{F}$ & $\%$ \\
\hline Tidak caring & 0 & 0 \\
Caring kurang & 2 & 6.7 \\
Caring cukup & 26 & 86.7 \\
Caring baik & 2 & 6.7 \\
Caring sangat baik & 0 & 0 \\
\hline TOTAL & 30 & 100 \\
\hline
\end{tabular}

Hasil dari pengisian kuesioner menunjukkan bahwa sebagian besar perawat sudah melakukan sepuluh faktor caratif caring dari Watson (2008), yaitu perawat memenuhi kebutuhan dasar manusia dengan penuh penghargaan, memecahkan masalah secara sistematis, menanamkan kepercayaan dan harapan, membantu menumbuhkan kepercayaan serta eksistensi fenomena dan spiritual, namun masih ada lima faktor caratif caring yang kurang dilakukan perawat yaitu kepekaan terhadap diri sendiri dan orang lain, kurang memberi dukungan mental, fisik, sosial dan spiritual, nilai humanistik dan altruistik, pembelajaran dan pengajaran secara interpersonal, dan pengekspresian perasaan positif dan negatif.

Berdasarkan hasil observasi peneliti terhadap caring perawat, bahwa perawat diruang intensif RSUD Dr.Soehadi Prijonegoro Sragen perilaku yang dilakukan perawat sudah cukup caring, hal itu ditunjukkan dengan sikap perawat tersenyum dan melakukan kontak mata terhadap keluarga, perawat terlihat peduli terhadap pasien dengan memeriksa cairan intravena pasien, memeriksa obat pasien, memberikan selimut dan merapikannya serta perawat bersikap ramah kepada keluarga pasien. Hal tersebut dapat menjadikan keluarga merasa nyaman. Hasil penelitian ini didukung oleh Fadilah (2016) didapatkan hasil dari sampel sebanyak 26 responden mayoritas caring perawat dalam kategori caring cukup yaitu sebanyak 22 responden $(84,6 \%)$.

b.Tingkat kecemasan keluarga pasien koma di ruang intensif RSUD Dr.Soehadi Prijonegoro Sragen

Tabel 3. Distribusi frekuensi responden berdasarkan tigkat kecemasan

\begin{tabular}{lll}
\hline Kategori & $\mathrm{F}$ & $\%$ \\
\hline Tidak ada kecemasan & 0 & 0 \\
Kecemasan ringan & 1 & 3.3 \\
Kecemasan sedang & 25 & 83.3 \\
Kecemasan berat & 4 & 13.3 \\
Kecemasan sangat berat & 0 & 0 \\
\hline TOTAL & 30 & 100 \\
\hline
\end{tabular}

Tabel Hasil penelitian ini menunjukkan bahwa sebagian besar responden mengalami kecemasan dalam kategori 
kecemasan sedang yaitu sebanyak 25 responden $(83.3 \%)$.

Stuart dan Sundeen (2007), menjelaskan bahwa saat mengalami cemas sedang, seseorang akan lebih memusatkan pada hal-hal penting. Mereka mengesampingkan yang lain, sehingga perhatian pada hal yang selektif dan mampu melakukan sesuatu dengan lebih terarah. Cemas sedang merupakan perasaan yang mengganggu bahwa ada sesuatu yang benar-benar berbeda, individu menjadi gugup atau agitasi. Gejala yang dapat muncul yaitu gelisah, sering berkemih, sakit kepala, pola tidur berubah, mudah marah dan kewaspadaan meningkat (Videbeck, 2012).

Hasil dari pengisian kuesioner juga menunjukkan bahwa rata-rata responden mengalami gejala kecemasan yang ditandai dengan gangguan gastrointestinal (sukar buang air besar, mual muntah, nyeri perut sebelum dan sesudah makan), gejala vegetatif (mulut kering, mudah berkeringat, pusing atau sakit kepala) dan tingkah laku atau sikap (gelisah, jari-jari gemetar, muka tegang) hal tersebut disebabkan karena hormon adrenalin meningkat sehingga dapat terjadi gangguan gastrointestinal, gejala vegetatif, dan gangguan tingkah laku atau sikap kemudian terjadi kecemasan.

Rangsangan pada kortek serebri diteruskan ke hipotalamus anterior selanjutnya menghasilkan hormon adrenalin kemudian dapat mempengaruhi fungsi saluran cerna dan mengakibatkan perubahan sekresi asam lambung, mempengaruhi motilitas dan vaskularisasi serta menurunkan ambang rangsang nyeri, hal tersebut ditandi dengan mual muntah, nyeri perut, mulut kering, pusing, gemetar dan gelisah (Arimbi, 2012). Penelitian ini sejalan dengan penelitian yang dilakukan oleh Peni (2014) didapatkan hasil bahwa dari sampel sebanyak 30 responden rata-rata mengalami kecemasan kategori kecemasan sedang yaitu sebanyak 13 responden (43.3\%). c.Hubungan caring perawat dengan tingkat kecemasan keluarga pasien koma di ruang intensif RSUD Dr.Soehadi Prijonegoro Sragen
Tabel 4. Hubungan caring perawat dengan tingkat kecemasan keluarga pasien koma di ruang intensif RSUD Dr. Soehadi Prijonegoro Sragen

\begin{tabular}{lll}
\hline & $r$ hitung & $\mathrm{P}$ value \\
\hline Caring perawat & $-0,678$ & 0,000 \\
\hline Kecemasan keluarga & & \\
\hline
\end{tabular}

Berdasarkan analisa data dari kuesioner yang disebarkan peneliti kepada 30 responden pada bulan Juli 2017 dengan menggunakan uji Kendall Tau p-value 0,000 (p-value < 0,05) maka diputuskan H0 ditolak dan Ha diterima, artinya ada hubungan yang signifikan antara caring perawat dengan tingkat kecemasan keluarga pasien koma di ruang intensif RSUD Dr.Soehadi Prijonegoro Sragen. Nilai korelasi didapatkan -0,678 menunjukkan korelasi negatif, yang artinya semakin baik caring perawat maka semakin ringan tingkat kecemasan keluarga pasien koma. Selain itu nilai korelasi -0,678 menunjukkan hubungan caring perawat dengan tingkat kecemasan keluarga pasien koma di ruang intensif memiliki hubungan yang kuat. Penelitian yang dilakukan oleh Setiyawan (2014) dengan judul hubungan perilaku caring perawat dengan tingkat kecemasan ibu akibat hospitalisasi anak (usia 0-12 tahun) di ruang rawat inap anak RSUD Ambarawa Kabupaten Semarang, hasil korelasi menunjukkan nilai pvalue $=0,000$ dan koefisien korelasi $-0,547$ artinya ada hubungan yang signifikan antara perilaku caring perawat dengan tingkat kecemasan ibu akibat hospitalisasi anak di ruang rawat inap anak RSUD Ambarawa.

Caring dapat menurunkan tingkat kecemasan keluarga pasien karena Menurut Potter dan Perry (2010) caring merupakan tindakan yang diarahkan untuk membimbing, mendukung individu lain atau kelompok dengan nyata atau antisipasi kebutuhan untuk meningkatkan kondisi kehidupan seseorang. Tuiuan dari caring adalah memberikan rasa aman dan nyaman untuk menurunkan kecemasan. Adapun bentuk pelaksanaan perilaku caring perawat yaitu : mendengarkan, kehadiran, sentuhan, memahami klien, dan berkomunikasi dengan baik.

Pada ruang intensif caring perawat sangat diperlukan karena tingkat ketergantungan yang tinggi dan kecemasan 
yang meningkat. Perilaku caring yang kurang dapat menimbulkan kecemasan pada keluarga pasien yang menunggui anggota keluarganya di rumah sakit. Tingkat dan bentuk kecemasan yang dialami oleh masing-masing keluarga akan berbeda-beda. Perawat yang perhatian dan care kepada keluarga dapat menurunkan tingkat kecemasan tersebut. Keluarga akan merasa dibimbing, dibantu, dan diberikan solusi atas masalah yang dihadapi. Dukungan berupa bimbingan umpan balik, pemecahan masalah, memberi dukungan, memberikan penghargaan dan memberikan perhatian.

\section{KESIMPULAN}

a. Karakteristik responden sebagian besar dalam kategori usia lansia awal yaitu sebanyak 16 responden $(53.3 \%)$, berjenis kelamin perempuan yaitu 19 responden (63.3), berpendidikan SMP yaitu 19 responden (63.3\%), dan memiliki hubungan dengan pasien sebagai anak yaitu 25 responden $(83.3 \%)$.

b. Caring perawat di ruang intensif RSUD Dr.Soehadi Prijonegoro Sragen sebagian besar masuk dalam kategori caring cukup sebesar $86.7 \%$

c. Tingkat kecemasan keluarga pasien koma di ruang intensif RSUD Dr.Soehadi Prijonegoro Sragen sebagian besar masuk dalam kategori kecemasan sedang sebesar $83.3 \%$

d. Ada hubungan caring perawat dengan tingkat kecemasan keluarga pasien koma di ruang intensif RSUD Dr.Soehadi Prijonegoro Sragen, dengan p-value 0,000 (pvalue $<0,05)$ arah hubungan kuat dengan nilai korelasi 0,678 .

\section{DAFTAR RUJUKAN}

Astutik, Wahyu \& Yonathan. (2008). Hubungan Tingkat Pendidikan Dengan Kecemasan Keluarga Pasien Dalam Menghadapi Perawatan Di Ruang ICU Rumah Sakit Umum Daerah Unit Swadana Pare.
Dwidiyanti, Meidiana. (2007). Caring, Kunci Sukses Perawat/Ners Mengamalkan Ilmu. Semarang : Hasani.

Elias, Yuliana dkk. (2013). Faktor-Faktor yang Mempengaruhi Tingkat Kecemasan Keluarga di Ruang High Care Unit (HCU) Rumah Sakit Immanuel Bandung. Prosiding.

Fadilah, Ratna. (2016). "Hubungan Caring Perawat Dalam Pelayanan Keperawatan Dengan Lama Rawat Inap Di RSUD Kota Salatiga". Skripsi. STIKes Kusuma Husada. Surakarta.

Ikawati VC \& Sulastri. (2011). "Hubungan Komunikasi Terapeutik Perawat Dengan Anggota Keluarga Terhadap Tingkat Kecemasan Keluarga Pada Pasien Yang Dirawat Di Unit Perawatan Kritis Di RSUD dr.Moewardi Surakarta". Skripsi. Fakultas Ilmu Kesehatan. Universitas Muhamadiyah Surakarta.

Lestari, Titik. (2015). Kumpulan Teori Untuk Kajian Pustaka Penelitian Kesehatan. Yogyakarta : Nuha Medika.

Peni, Tri. (2014). Kecemasan Keluarga Pasien Ruang ICU Rumah Sakit Daerah Sidoarjo. Hospital Majapahit. Volume 6. No.1.

Potter \& Perry. (2010). Fundamental Keperawatan. Buku 1. Edisi 7. Jakarta: Salemba Medika.

Setiawati, B. (2009). "Kesabaran Anak Dalam Merawat Orang Tua Yang Sakit Kronis”. Skripsi. Fakultas Psikologi. Universitas Muhamadiyah Surakarta. Setiyawan, Dhika. (2014). Hubungan Perilaku Caring Perawat Dengan Tingkat Kecemasan Ibu Akibat Hospitalisasi Anak (Usia 0- 12 Tahun) Di Ruang Rawat Inap Anak RSUD Ambarawa Kabupaten Semarang.

Stuart \& Sundeen. (2007). Buku Ajar Keperawatn Jiwa.

Edisi 5. Jakarta : EGC.

Jurnal AKP. 
Sugiyono. (2012). Metode Penelitian Pendidikan Pendekatan Kuantitatif, Kualitatif dan $R \& D$. Bandung : Alfabeta.

Videbeck, SL. (2012). Buku Ajar Keperawatan Jiwa. Jakarta : EGC.

Watson, Jean. (2008). Nursing The Philosophy and Sciene Of Caring, Revised Edition. Colorado :
University Press Of Colorado. Journal of Watson's theory of human caring and subjective living experiences.

Cite this article as: Agustin WR dkk (2020). Hubungan Caring Perawat Dengan Tingkat Kecemasan Keluarga Pasien Koma Di Ruang Intensif, Jurnal Ilmiah Media Husada. 9 (1), 21-77. https://doi.org/10.33475/jikmh.v9i1.212 